University of South Florida

DIGITAL COMMONS Digital Commons @ University of @ UNIVERSITY OF SOUTH FLORIDA South Florida

\title{
Transit Value Capture Coordination: Case Studies, Best Practices, and Recommendations
}

CUTR

Follow this and additional works at: https://digitalcommons.usf.edu/cutr_nctr

\section{Recommended Citation}

"Transit Value Capture Coordination: Case Studies, Best Practices, and Recommendations," National Center for Transit Research (NCTR) Report No. CUTR-NCTR-RR-2015-10, Center for Urban Transportation Research, University of South Florida, 2015.

DOI: https://doi.org/10.5038/CUTR-NCTR-RR-2015-10

Available at: https://scholarcommons.usf.edu/cutr_nctr/52

This Technical Report is brought to you for free and open access by the National Center for Transit Research (NCTR) Archive (2000-2020) at Digital Commons @ University of South Florida. It has been accepted for inclusion in Research Reports by an authorized administrator of Digital Commons @ University of South Florida. For more information, please contact digitalcommons@usf.edu. 


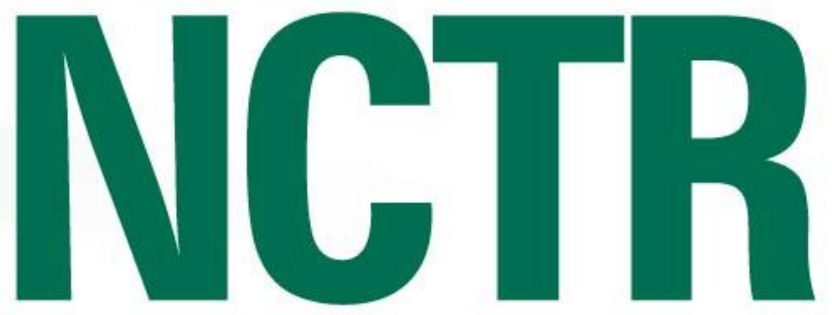

NATIONAL CENTER for TRANSIT RESEARCH

\title{
Transit Value Capture Coordination: Case Studies, Best Practices, and Recommendations
}

\author{
Final Report
}

February 2015

PROJECT NO.

2117-9060-02-C

PREPARED FOR

National Center for Transit Research (NCTR) 


\section{Disclaimer}

The contents of this report reflect the views of the authors, who are responsible for the facts and the accuracy of the information presented herein. This document is disseminated under the sponsorship of the Department of Transportation University Transportation Centers Program and the Florida Department of Transportation, in the interest of information exchange. The U.S. Government and the Florida Department of Transportation assume no liability for the contents or use thereof.

The opinions, findings, and conclusions expressed in this publication are those of the authors and not necessarily those of the State of Florida Department of Transportation. 


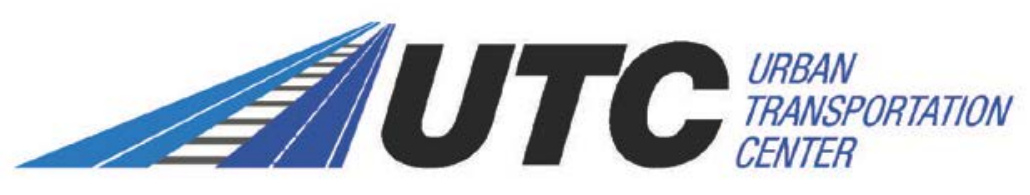

The Urban Transportation Center at the University of Illinois at Chicago

\section{Transit Value Capture Coordination: Case Studies, Best Practices, and Recommendations}

\section{February 2015}

This report was produced with funding from:

National Center for Transit Research (NCTR),

a US DOT-OST National University Transportation Center

National University (NURail) Center, a US DOT-OST Tier 1 University Transportation Center 
Transit Value Capture Coordination: Case Studies, Best Practices, and Recommendations

Stephen E. Schlickman

Urban Transportation Center

University of Illinois at Chicago

412 S. Peoria Street

Suite 340

Chicago, IL 60607

sschlick@uic.edu

312-355-3656

Jordan Snow (corresponding author)

Urban Transportation Center

University of Illinois at Chicago

412 S. Peoria Street

Suite 340

Chicago, IL 60607

jsnow7@uic.edu

312-996-9357

Janet Smith

Nathalie P. Voorhees Center

University of Illinois at Chicago

400 S. Peoria Street

Suite 2100

Chicago, IL 60607

janets@uic.edu

312-996-5083

Yittayih Zelalem

Nathalie P. Voorhees Center

University of Illinois at Chicago

400 S. Peoria Street

Suite 2100

Chicago, IL 60607

yittazel@uic.edu

312-996-6674

Tom Bothen

Urban Transportation Center

University of Illinois at Chicago

412 S. Peoria Street

Suite 340

Chicago, IL 60607

tbothen@uic.edu

630-334-1656 
Metric Conversion

\begin{tabular}{|c|c|c|c|c|}
\hline SYMBOL & WHEN YOU KNOW & MULTIPLY BY & TO FIND & SYMBOL \\
\hline \multicolumn{5}{|c|}{ LENGTH } \\
\hline in & inches & 25.4 & millimeters & $\mathrm{mm}$ \\
\hline ft. & feet & 0.305 & meters & $\mathrm{m}$ \\
\hline yd. & yards & 0.914 & meters & $\mathrm{m}$ \\
\hline mi & miles & 1.61 & kilometers & $\mathrm{km}$ \\
\hline \multicolumn{5}{|c|}{ VOLUME } \\
\hline fl. oz. & fluid ounces & 29.57 & milliliters & $\mathrm{mL}$ \\
\hline gal & gallons & 3.785 & liters & $\mathrm{L}$ \\
\hline $\mathrm{ft}^{3}$ & cubic feet & 0.028 & cubic meters & $\mathrm{m}^{3}$ \\
\hline$y d^{3}$ & cubic yards & 0.765 & cubic meters & $\mathrm{m}^{3}$ \\
\hline \multicolumn{5}{|c|}{ NOTE: volumes greater than $1000 \mathrm{~L}$ shall be shown in $\mathrm{m}^{3}$} \\
\hline \multicolumn{5}{|c|}{ MASS } \\
\hline oz. & ounces & 28.35 & grams & $\mathrm{g}$ \\
\hline lb. & pounds & 0.454 & kilograms & $\mathrm{kg}$ \\
\hline $\mathbf{T}$ & Short tons (2000 lb.) & 0.907 & $\begin{array}{c}\text { megagrams } \\
\text { (or "metric ton") }\end{array}$ & Mg (or "t") \\
\hline \multicolumn{5}{|c|}{ TEMPERATURE (exact degrees) } \\
\hline${ }^{\circ} \mathbf{F}$ & Fahrenheit & $\begin{array}{c}5(F-32) / 9 \\
\text { or }(F-32) / 1.8\end{array}$ & Celsius & ${ }^{\circ} \mathrm{C}$ \\
\hline
\end{tabular}




\section{Technical Report Documentation}

\begin{tabular}{|l|l|l}
\hline $\begin{array}{l}\text { 1. Report No. } \\
\text { 2117-9060-02-C }\end{array}$ & 2. Government Accession No. & 3. Recipient's Catalog No. \\
\hline $\begin{array}{l}\text { 4. Title and Subtitle } \\
\text { Transit Value Capture Coordination: Case Studies, Best } \\
\text { Practices, and Recommendations }\end{array}$ & February 2015 \\
\hline
\end{tabular}

6. Performing Organization Code

\begin{tabular}{l|l} 
7. Author(s) & 8. Performing Organization Report No.
\end{tabular}

Stephen E. Schlickman

Urban Transportation center

University of Illinois at Chicago

412 S. Peoria Street, Suite 240

Chicago, IL 60607

9. Performing Organization Name and Address

10. Work Unit No. (TRAIS)

National Center for Transit Research

Center for Urban Transportation Research (CUTR)

University of South Florida

4202 East Fowler Avenue, CUT100

Tampa, FL 33620-5375

11. Contract or Grant No.

12. Sponsoring Agency Name and Address

13. Type of Report and Period Covered

Research and Innovative Technology Administration

U.S. Department of Transportation

Mail Code RDT-30, 1200 New Jersey Ave SE, Room E33

Washington, DC 20590-0001

14. Sponsoring Agency Code

\section{Supplementary Notes}

\section{Abstract}

This study is based on the hypothesis that coordination between transit capital planners, municipal taxation authorities, and private developers and stakeholders can be a benefit to transit capital projects that choose to use value capture as a funding mechanism. Value capture is the means by which the increase in property or other values is tied to investments in infrastructure and other amenities and, through taxation or other agreements beneficiaries of the increase in property value help fund the improvements. The research team engaged in case studies of projects in Chicago, New York, San Francisco and Washington D.C. to observe how coordination between the relevant parties is conducted and, from the information gathered, a series of conclusions, best practices and recommendations were compiled. It is the conclusion of this study that in order for coordination of value capture mechanisms to be effective there must be a focus on both ingrained staff knowledge in the public sector as well as unique organizational attributes in the municipal and transit organizations that interface with private developers.

\begin{tabular}{|c|c|c|c|}
\hline \multicolumn{2}{|c|}{$\begin{array}{l}\text { 17. Key Words } \\
\text { Transit, taxation, capital planning, value capture }\end{array}$} & \multicolumn{2}{|c|}{$\begin{array}{l}\text { 18. Distribution Statement } \\
\text { No restrictions }\end{array}$} \\
\hline $\begin{array}{l}\text { 19. Security Classification } \\
\text { (of this report) } \\
\text { Unclassified }\end{array}$ & $\begin{array}{l}\text { 20. Security Classification } \\
\text { (of this page) } \\
\text { Unclassified }\end{array}$ & $\begin{array}{l}\text { 21. No. of Pages } \\
21\end{array}$ & 22. Price \\
\hline
\end{tabular}




\section{ABSTRACT}

This study is based on the hypothesis that coordination between transit capital planners, municipal taxation authorities, and private developers and stakeholders can be a benefit to transit capital projects that choose to use value capture as a funding mechanism. Value capture is the means by which the increase in property or other values is tied to investments in infrastructure and other amenities and, through taxation or other agreements beneficiaries of the increase in property value help fund the improvements. The research team engaged in case studies of projects in Chicago, New York, San Francisco and Washington D.C. to observe how coordination between the relevant parties is conducted and, from the information gathered, a series of conclusions, best practices and recommendations were compiled. It is the conclusion of this study that in order for coordination of value capture mechanisms to be effective there must be a focus on both ingrained staff knowledge in the public sector as well as unique organizational attributes in the municipal and transit organizations that interface with private developers.

\section{ACKNOWLEDGMENTS}

The research contained within this report would not have been possible without funding made available by the National University Rail (NURail) Center, a US DOT-OST Tier 1 University Transportation center; the National Center for Transit Research (NCTR), a US DOT-OST National University Transportation Center; and the Illinois Department of Transportation (IDOT). In addition to our funding partners the input of SFMTA, WMATA, MTA, CTA; their municipal counterparts; and the private developers interviewed provided invaluable input to this study. 


\section{INTRODUCTION}

The hypothesis of this study is that transit authorities who have a significant degree of success with value capture funding (funding mechanisms by which the increase in land value associated with infrastructure and other improvements are harnessed to generate revenue for said improvements) also have a good working relationship with their local municipal taxing authorities and the private development community. To establish this theory, a case study approach is utilized to analyze good examples of transit value capture. Additionally the project focuses on the largest and oldest rail systems in the nation, which also have the greatest national share of the backlog of unfunded transit capital needs. These systems have been encouraged by the Federal Transit Administration to utilize value capture financing to address those needs. Through a process of preliminary interviews with staff at many old rail transit agencies the list of suitable cities with experience in coordinating value capture was narrowed down to San Francisco, Washington DC, and New York City. In addition to these three cities, Chicago was chosen to be a comparative example of where there is great potential for value capture to be used more extensively.

Each following case study section will briefly outline the current makeup and condition of the city's transit system including any direct and indirect connections between the transit agency and the local taxing authorities. From that point a single exemplary project is described covering its history, relation to the rest of the transit system, and sources of funding. Then an account is provided of how transit capital planners, taxing authorities, and private developers coordinated to secure funding outside of typical sources. Further, any ongoing commitments to coordination as evidenced by public releases, reporting documents, as well as this research group's conversations with stakeholders will be described and assessed.

It should be noted that interviews were conducted in each city with individuals and groups representative of transit agencies, municipal governments, private developers, and other public and private stakeholders. This study withholds the names of participants in order to protect their anonymity and ensure their full cooperation.

\section{CASE STUDIES}

\section{San Francisco - Parkmerced}

\section{Introduction}

Most of the forms of surface transportation, excluding Bay Area Rapid Transit (BART) trains, operating in San Francisco are managed and operated by a single entity, the San Francisco Municipal

Transportation Agency (SFMTA). Within SFMTA exists the San Francisco Municipal Railway, known colloquially as Muni. Muni service began in 1912 after a period of rebuilding in San Francisco after the 1906 earthquake (1). Today, Muni operates buses, cable cars, and its Muni metro rail service.

Muni's average weekday rail ridership is 173,500 passengers and its network consists of 71.5 miles of track spread across six lines. Most of the stations are above ground but there are also nine subway stations and a few tunneled tracks (1). SFMTA faces a significant capital improvement project backlog. As of 2013 the backlog was estimated at $\$ 2.2$ billion. About $\$ 510$ million per year address is needed to address current and backlog needs by 2033. Available annual revenues total only $\$ 250$ million (1). This puts SFMTA in a precarious position to fund future capital projects.

\section{Project Information}

One project has been identified by local agencies, public stakeholders and the private development community on the west side of San Francisco. The Parkmerced development was conceived and constructed by the Metropolitan Life Corporation between 1941 and 1951. Upon completion it consisted of over 3,400 housing units of which about half were garden units and the other half were tower and patio units (2). Over the last 60 years the property has seen three changes in ownership. The current ownership 
is Parkmerced Investors Properties, LLC.

For the entirety of Parkmerced's existence the Muni M Line has run past the development with a stop just to the north at San Francisco State University. The acquisition of the development by Parkmerced Investors Properties, LLC came with the desire by the company to reimagine what has become outdated and inadequate housing stock (2). As part of this planned redevelopment both the city and the developer perceived value in revitalizing transit and pedestrian access for the Parkmerced neighborhood.

The redevelopment of Parkmerced required over 500 community organization meetings beginning in 2010 to hone the final vision for the renovation of 3,221 existing rental units and the construction of an additional new 5,679 units over an approximately 30- year period. This massive project involves street realignment as well as the rerouting and extension of the Muni M Ocean View light rail line along $19^{\text {th }}$ Avenue adjacent to Parkmerced to improve pedestrian safety and commuter movement. The rail improvements are scheduled to commence in 2018.

The revitalization plans include a large menu of changes and, according to a developer agreement with the City of San Francisco, the developer will be responsible for almost all of the costs associated with any form of transportation facility improvement. Of particular interest to this research project is the developer's commitment to fund the relocation and addition of Muni metro service along the M line, including the planning for a larger, more transformative corridor-wide transit configuration (3).

This is a unique form of joint development value capture. Usually in a joint development project the transit agency would fund and retain the bulk of responsibility to construct the facility with the developer agreeing to fund part of it, i.e., returning value to the transit agency. In this case the developer is offering to pay for and to take on the full responsibility for construction, though as the preconstruction plans evolve SFMTA retains the option of being the constructor (2).

Currently the M-line travels in the median of heavily-trafficked 19th Avenue (California State Highway 1), south from San Francisco State University past and turning southeast away from Parkmerced. The joint development project, as is depicted in Figure 1, would direct the M-line into Parkmerced to serve the center of the project, rather than the periphery, and give pedestrians access to the light rail trains without needing to cross $19^{\text {th }}$ Avenue. At the southern end of the neighborhood the line would split to join its original alignment with a branch to terminate with a "tail track" and station at southern most reach of the Parkmerced community (3).

From the perspective of the municipality and the transit agency, planning is paramount and dedication to a long process is mandatory. Planning for the proposed $19^{\text {th }}$ Avenue Muni realignment and the Parkmerced connector began in 2008 and addressed two major SFMTA concerns about the current transit alignment: its access challenges in the median of Highway 1 and the lack of a "trail track" facility to store or turn back trains that may be disabled or needed for demand surges.

However, as the alignment could only be revised within Parkmerced proper, it includes several right-turn track configurations which would serve to rejoin the remaining median segments with at-grade crossings of Highway 1 . These turns limit reliability and transit travel-time benefits for MLine along the overall corridor. While the redeveloped Parkmerced project, with the proposed rail realignment, was approved in 2011, an agreement to address these remaining concerns was secured between the City, Parkmerced, San Francisco State University and the Stonestown shopping center to the north to co-fund a three-year corridor-wide study of the entire light rail alignment (SFMTA meeting, unpublished data). The study considers two grade-separated highway crossings and a smoother, less angular track alignment (along with substantial landscape/urban design amenities and pedestrian and cycling upgrades).

Should the revised alignment envisioned by the study receive environmental clearance by 2018, the Parkmerced developers would re-allocate the funds committed to the rail alignment approved in 2011 to co-fund the broader transportation investment, in a likely private-public partnership with the City, the University and Stonestown. The University has also agreed to commit funding to an improved M-Line station. If, at the conclusion of the study, there is insufficient support to implement the re-aligned M-Line, Parkmerced is entitled to proceed with construction of the rerouted light rail tracks as approved in 2011. In either case, it is expected that construction could begin on the light rail alignment by 2020 with a threeyear completion. (4) 
The Parkmerced-only rail configuration has been estimated at \$70 million (2011 cost estimate). No final cost estimates for the broader $19^{\text {th }}$ Avenue project have been developed though a rough order of magnitude estimates it to be from \$420-\$720 million. Other improvements further up the line toward downtown San Francisco are first being considered by the SFMTA.

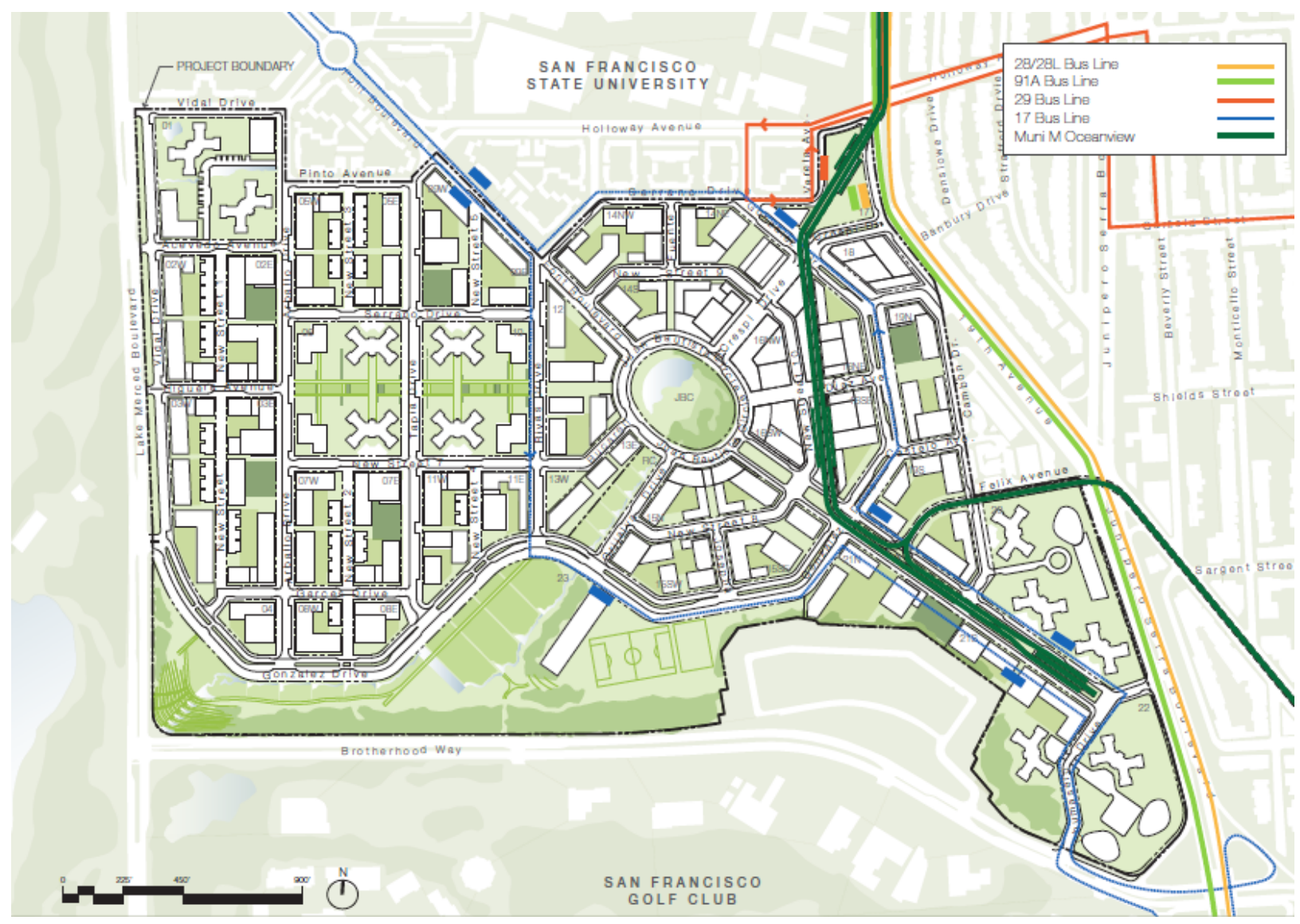

FIGURE 1 Parkmerced area with transit modifications (3).

\section{Coordination}

Even with this project in its very early stages, the activity to get to the joint development agreement thus far has relied on staggering amounts of community involvement and cooperation between local and regional agencies.

According to officials with the City of San Francisco there have been over 500 meetings conducted since 2006 with participation from dozens of agencies. The main partners in development have been:

- City of San Francisco’s Office of Economic and Workforce Development

- SFMTA

- City Planning \& Municipal Executive’s Association

- Other regional transportation providers: BART, Caltrans, ABAG, MTC

- Community \& Advocacy Groups

Through meetings of residents, agencies, and the developer the terms of the joint agreement were passed in late 2010 and, since then, progress on the project has continued. Despite the lack of actual progress on the transit extension, the joint development agreement paves the way. Without the early engagement by all involved parties there likely would not have been an agreement at all. 
A supporting attribute of effective transit planning is that the real estate development community is informed of necessary zoning and building changes to eliminate uncertainty for the building of residential, retail and office properties. Increased land density could generate added fare box revenue. All households at Parkmerced will be subject to the cost of the transit improvements, which will be paid as part of the rent. Students at SF State may also pay a "Class Pass" fare as part of tuition. Such practices may be applicable for projects in other cities. San Francisco State University will restrict parking after the transit improvements are completed. This policy is an outcome of a "transit first" policy adopted by San Francisco. (4)

An executive with the SFMTA noted the importance of community engagement and project prioritization. Extensive community input from travelers, residents, businesses and institutions resulted in defining a plan which had a 70 percent approval from the community for the broader extension. Planning included minimization of transit conflict between pedestrians, bikers, cars, buses and trucks. This outcome produced a plan which was defined and understood by all parties. The plan moved forward for action. Through this process the City and the SFMTA avoided criticism or challenges as the community was in full support. Local community groups and San Francisco State University which is across from Parkmerced contributed money for project planning and a new station.

The SFMTA executive also commented that "some developers just do not get transit." Sharing in the local vision is critical. In the Parkmerced context, the developer went over and above the stipulations of the development agreement to affirm their commitment to the transit improvements. (SFMTA interview, unpublished data)

\section{Project Conclusions}

A special factor for this project was the involvement of savvy staff members of the City of San Francisco who have significant development and intergovernmental experience. From the earliest stages of contact between the city, developers, and various stakeholders it was apparent that the open minds and willingness to work with non-traditional partners have made the extension and reroute at Parkmerced possible. For Parkmerced this cooperation was encouraged and supervised by a point person who possessed knowledge of the development players, real estate transactions, transit planning, joint development agreements and associated contacts for each aspect of the project both in and out of San Francisco's city government.

The success of this project was based on a synergistic team from the mayor's office, transportation planners, community leaders and the development team. Our research revealed that top down leadership with a refined urban vision is a critical element for the success of such projects. The mayors' office provided an intra-agency ombudsman with 12 years of city government experience who moved seamlessly across departments and city agencies to ease procedural bottlenecks. The San Francisco Municipal Transit Agency provided a senior Urban Planning Initiatives Manager well experienced in transit, bicycle, streets and sidewalks and accessibility projects to guide all modes of people movement.

The development team was comprised of patient and experienced urban real estate developers sensitive to the needs of a diverse community of interests. The team was led by an individual with 18 years of experience in construction management, restoration and historic preservation. The developer is also a native of San Francisco. It is believed by the authors that plan members with a long local history and civic involvement are also crucial to the success of the project.

\section{Washington, DC - NoMa-Gallaudet U}

\section{Introduction}

The Washington Metropolitan Area Transit Authority's (WMATA) rail system was planned and constructed in the late 1960s and 1970s and began initial operation in 1976. Today the system consists of 106 miles of heavy rail with 86 stations on five lines (not including the recently opened Silver Line). As of 2012 the system averaged about 1.2 million riders per day making WMATA's rail system the second busiest in the country (5). 
WMATA, a regional agency, exists as a separate public entity from Washington DC's city government and the surrounding state and local governments in Maryland and Virginia. Like many other large transit systems in the United States, WMATA's rail system faces daunting maintenance backlogs. Unlike similar transit agencies elsewhere in the country, WMATA does not have its own tax dedicated to its financial needs. WMATA relies on federal appropriations and annual negotiations with Washington DC and the surrounding local governments in order to complete capital projects and sustain operations (6, 7). For this reason WMATA has been aggressively seeking alternate forms of revenue for station construction and rehabilitation.

\section{Project Information}

Beginning in 1997 the District engaged in a planning process that identified the area north of Massachusetts Avenue, south of New York Avenue and just east of North Capitol Street as a prime location for new development that could be well-served by a WMATA infill station (8). A 1999 study by WMATA identified that less than $50 \%$ of the residents within $3 / 4$ of mile of the New York Avenue/Florida Avenue intersection owned a car (8). This initial planning and study concluded that a new station was desirable between Union Station and Rhode Island Avenue on the Red Line (see Figure 2).

The final cost of the station was \$103.7 million and it opened in 2004. The District government pledged \$53.7 million and the federal government provided $\$ 25$ million. The remaining \$25 million was funded via a Special Taxing District, the value capture element, the origins and details of which will be discussed in the next section. Upon opening it was called New York Ave-Florida Ave-Gallaudet U. In 2012 the name was changed to NoMaGallaudet U to reflect the District's desire to treat the area as a single neighborhood rather than a collection of intersecting streets $(8,9)$.

\section{Coordination}

From the beginning of the planning process, the District government engaged in meetings with private developers and local landowners to measure their willingness to assist in the construction of the station. Within the first two years of initial project identification there was an agreement forged with local landowners to provide what, at the time, was considered to be one third of project costs - \$25 million (8). This agreement was achieved largely due to the work of the District's Department of Housing and Community Development via an entity that would come to be known as Action 29. Action

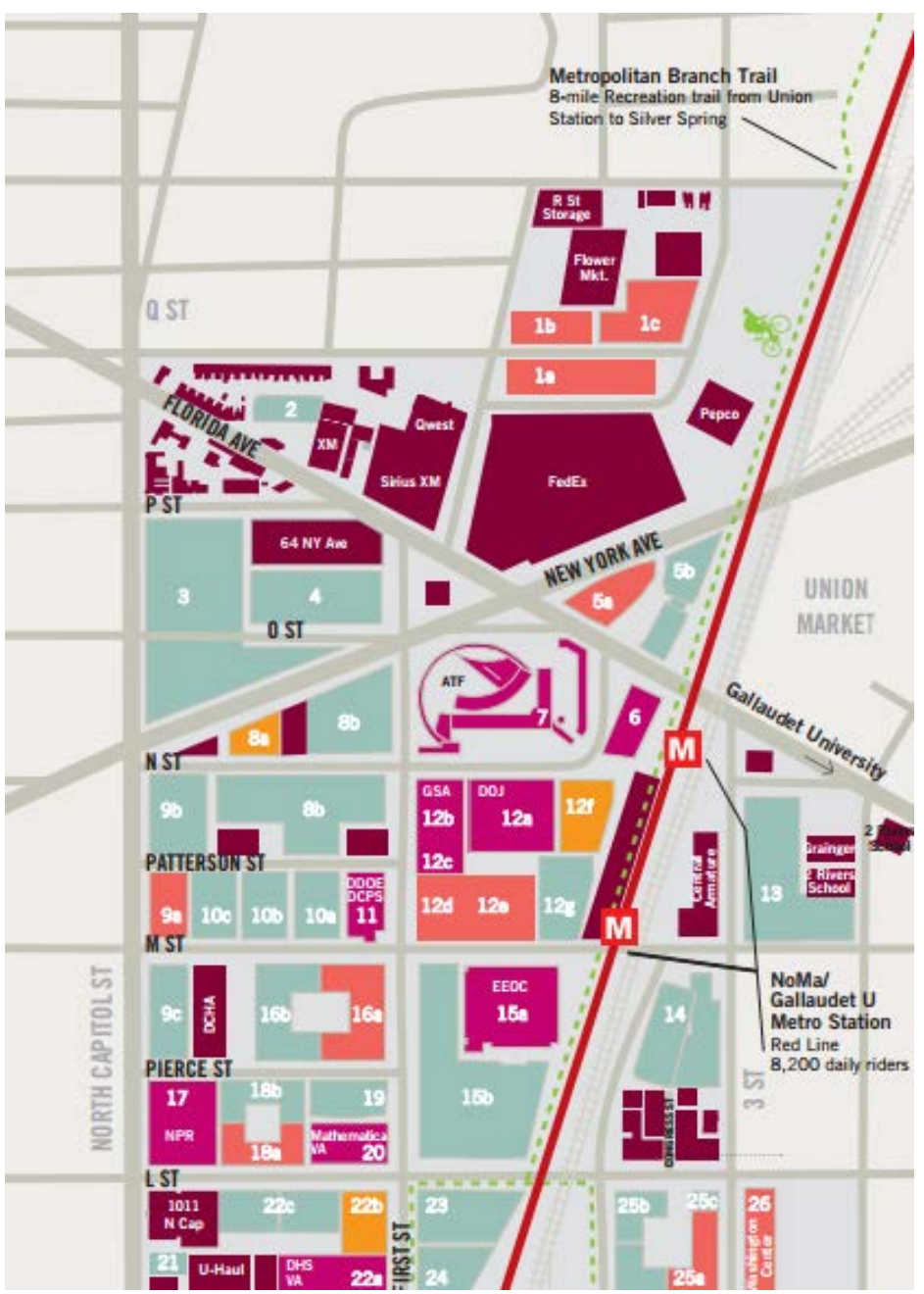

FIGURE 2 NoMA-Gallaudet $U$ station area map (source: http://www.nomabid.org/wpcontent/uploads/2011/02/NoMaDevelopmentMap-Final.pdf). 
community members and served as the negotiating party while terms of the special taxing district were decided between the District and the local landowners.

For a time the local landowners demanded that any contribution by them to the project through a special assessment be made up via future rebates on property tax increases. This demand was not acceptable to the District. The landowners and District eventually agreed to a special assessment district that would extend a half-mile out from the proposed station for 30 years to service the $\$ 25$ million bonds debt (8). The district began collecting the assessment in 2002.

\section{Project Conclusions}

By engaging local, private landowners and developers very early in the planning process, both the District government and WMATA achieved support for and financial assistance from the special assessment district. This project is an example of how the positive influence of early coordination can lead to a transit value capture funding source. WMATA has continued to embrace this form of early communication and coordination as they review for redevelopment the large surface parking areas at outer the rail system's stations (WMATA Staff Interview, unpublished data).

As previously noted WMATA does not have a dedicated source of funding. For construction of a new station, the agency utilized value capture in the form of a special assessment district extending one half mile from the new station. Local community leaders were also involved in the decision process.

Since the completion of the NoMa-Gallaudet infill station in 2004, there has been $\$ 3$ billion of private investment near the station involving eight million square feet of office, retail, residential and hotel construction. There are currently 20 projects in negotiation and planning stages.

(WMATA Staff Interview, unpublished data)

The Authority has an administrator with real estate development and transit experience to foster future transit oriented developments. Such development is expected to attract new riders and support new employment centers to promote a "synergistic relationship between transit and development." Analysis by WMATA has revealed the following property value increases as a result of proximity to a station (WMATA Staff Interview, unpublished data):

- $\quad-6.8 \%$ for residential

- $-9.4 \%$ for multifamily

- $\quad-8.9 \%$ for commercial property

To facilitate the utilization of value capture strategies, the agency has developed a 52- page joint development solicitation which outlines the requirements for the development of WMATA land by private developers. This is another example of how planning and communication dramatically improve the development process to minimize uncertainty for all parties. Using the joint development solicitation as a guide WMATA seeks to enter into Joint Development Agreements with highly experienced local developers for transit-oriented developments that promote "place making, enhance the local tax base, increase transit ridership and provide revenue for WMATA.” The solicitation includes:

1. Administrative and Contractual Information

2. Proposal Preparation/Format/Content/Submission

3. Proposal Review, Evaluation, Developer Selection and Post-Selection Process

4. WMATA's Non-Negotiable Requirements and Conditions

5. Additional Joint Development Requirements and Procedures

6. Definitions

7. Proposal Form

8. Irrevocable Standby Letter of Credit

9. Right of Entry Agreement

10. Certifications

Unlike the necessarily collaborative process required for Parkmerced in San Francisco, WMATA is a governmental agency which controls sites adjacent to station locations and seeks to maximize site 
value using a highest and best use process as a function of local market conditions and site characteristics. This development process is led by a senior manager with significant private sector real estate development experience as well as urban transit experience. This manager prepares and issues extensively detailed solicitation proposals to local real estate developers. The solicitation includes the stringent requirement that the developer have a qualified and experienced team. The developer must provide detailed team member resumes. In terms of its proactive approach for potential transit redevelopment sites across its service area, this real estate management process was unique to the regions this team studied.

WMATA has embraced its role as an owner of land assets. It has hired and utilized staff familiar with municipal taxation and development and with the private developer community to review existing properties and prepare developer briefing materials and processes to induce station redevelopment opportunities in areas ripe for joint development, special taxing districts, or other forms of value capture.

\section{New York City - Hudson Yards}

\section{Introduction}

New York City hosts one of the oldest and the busiest transit system in the world. The MTA's rail transit system is millions of people each day rely on it to move about the city. Without this system, the mobility to sustain the United States' largest business center would be impossible. Thus, New York presents an excellent opportunity to study how local and regional governments interact to fund capital improvement and expansion projects.

\section{Project Information}

The Hudson Yards redevelopment project provides instructive examples of intergovernmental and developer coordination to support a project by way of intense planning, careful communication, and innovative funding and finance methods, such as transit value capture. The Hudson Yards development project covers the East and West Rail yards on the west side of Midtown Manhattan and encompasses a total of 45 square blocks. In order for the project to be successful, it was mandatory for the Number 7 subway transit line to be extended 1.7 miles from Times Square to $11^{\text {th }}$ and $34^{\text {th }}$ streets at a cost of $\$ 3$ billion.

The earliest official plans for revitalizing the Hudson Yards area were included in a 1988 MTA study on development opportunities near the rail yards depicted in Figure 3. The MTA reached the conclusion that in order to encourage transit oriented mixed-use properties in the area, cooperation from the city government would be needed for re-zoning (9). This initially did not produce results. In the early 1990s the area south of the Jacob K. Javits Convention Center was re-zoned to allow for a floor area ratio (FAR) of up to 10. No development resulted. From that point and into the early 2000s several studies continued to shape the modern Hudson Yards project. The model of cooperation between the MTA, the city, and potential developers emerged. 
Those studies, conducted by various development and planning-focused entities within the city, acknowledged that to spur development in the area transit access must be a factor. The studies had significant developer input and identified a Number 7 line rail extension to the Hudson Yards neighborhood and further re-zoning efforts (to enhance the unsuccessful Javits re-zoning from 1993). This resulted in the creation of the Hudson Yards Infrastructure Corporation (HYIC) in 2004 and the Hudson Yards Development Corporation (HYDC) in 2005 (10). The main goal of the HYIC, staffed entirely by the city's Office of Management and Budget, is to control the funding and financing essential to building new amenities within the redevelopment area. The mission of the HYDC, with nine full-time staff employed specifically by the corporation, is to manage the city's redevelopment plan. Another function of the HYDC is that it coordinates input from a variety of stakeholders including the MTA and private developers.

The re-zoning effort involved an FAR arrangement where developers could pay a premium to develop at a higher than standard FAR. The proceeds of this market, referred to as a District Improvement Bonus (DIB), and from tax increment financing (TIF), are used to support debt financing for the transit extension. Overall, the extension of the Number 7 line is expected to cost around \$2.3 billion which is being funded by two separate bond issuances, one in 2006 and one in 2011. These debt issuances are the sole source of funding for the project, making it the largest transit value capture initiative in the country. To date the success of the financing scheme can be judged by the bond ratings of A, A2 and A by Standard \& Poor's Ratings, Moody's, and Fitch respectively. Further, that the bonds continue to hold their valuation shows an appetite for the market to support major selfsustaining, transitdependent developments (11). In the event that the

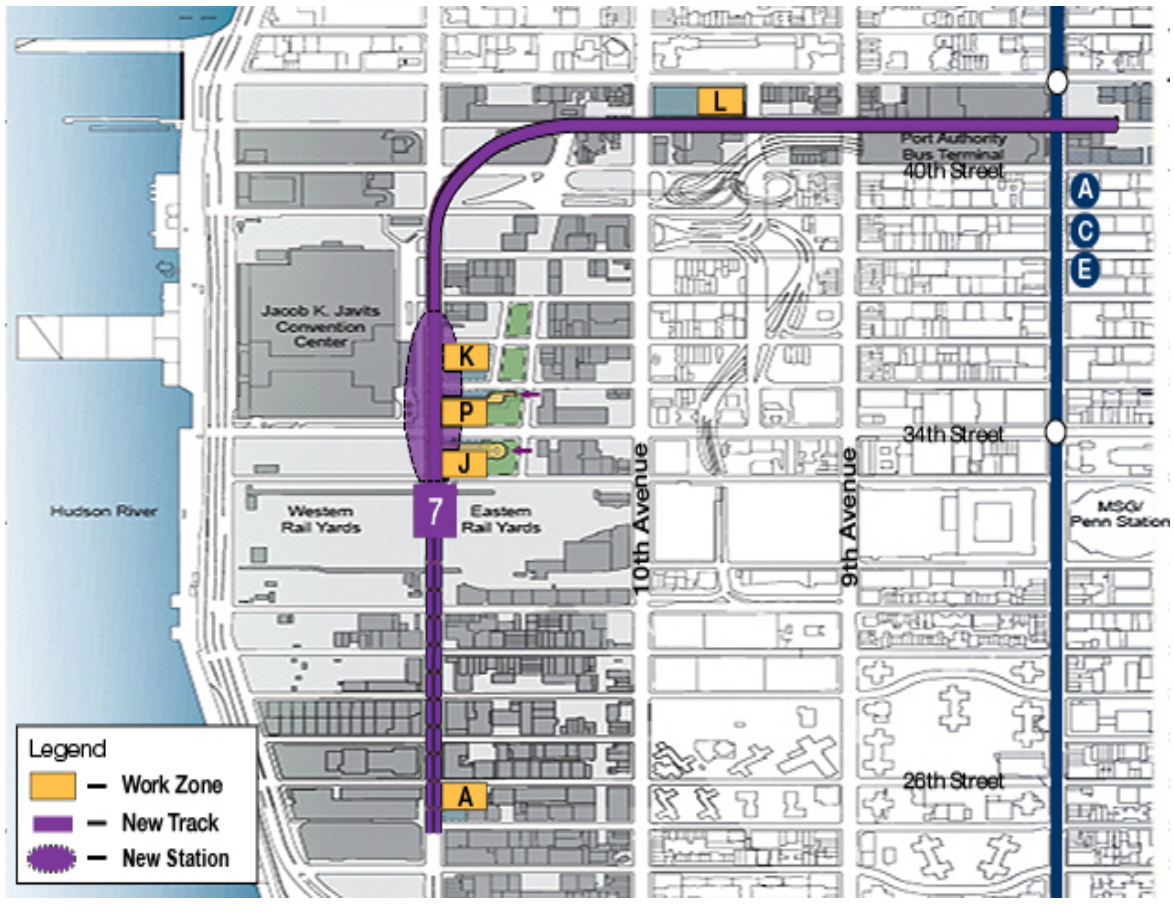

FIGURE 3 MTA 7 Line Extension into Hudson Yards site (Source: http://web.mta.info/capital/no7_alt.html). various revenue sources associated with the HYIC bond issuances do not cover all project costs, the city of New York would be responsible for any default on debt service that could occur (12). This "backstop" is not rooted in city or state ordinance or statute, but according to van der Veen's study it is a financial necessity for the city. Failure of this project could stall many other development projects and cripple the transit system's extension into Hudson Yards (12).

\section{Coordination}

None of these developments would have been possible without the close cooperation of city and MTA officials in coordination with private developers throughout the planning process. In the early 1990s the re-zoning effort which resulted in little development took place in a vacuum with no effort to connect development with transit. The process through the last decade and leading up to present day has been 
inclusive and continues to attract new development. The Number 7 line extension is slated to begin revenue service at some point later this year.

In particular, the city's creation of the HYIC and HYDC provided the enabling environment necessary for developers to begin exploring their own massive capital investments and provide the financing via city-created mechanisms. The HYDC in particular, through its function of communicating the city and MTA's vision for Hudson Yards and coordinating with potential developers, contributed greatly to the initial success of the Hudson Yards bond rollout (12).

From a development perspective, one of the key planning attributes contributing to the potential success of Hudson Yards is that the zoning densities for the 45 square block area have been defined. This means real estate developers know the type and size of each property that can be built on each of the sites. Removal of an often lengthy and arduous building approval process is a boon to the development community as it minimizes uncertainty and saves time. In both Parkmerced and Hudson Yards, a managing developer was identified early on in the process. Risk amelioration is a benefit to having the developer as an integral member of the project.

\section{Project Conclusions}

By learning the lessons of a failed re-zoning from the early 1990s and cooperating with both private developers and transit planners, the City of New York, in the form of the HYIC and HYDC helped form a benchmark for coordinating and achieving a novel market approach to value capture. This project has a distant horizon. The full success of the financing may not be known for some time. Early success, however has been achieved. The financing obtained initial credit-worthy ratings which helped to spur early redevelopments in the Hudson Yards area. The efforts of coordination between public and private entities were critical in achieving this.

\section{Chicago}

\section{Introduction}

The Chicago Transit Authority (CTA) system faces the same capital funding issues as the other large transit systems in the United States. A recent gubernatorial task force assigned to address governance and funding issues concerning the Regional Transit Authority (RTA) and its service boards (CTA, Metra, and PACE) reiterated that there was a regional backlog of at least $\$ 20$ billion and that the outlook for ongoing growth in federal and state grant support is poor due to myriad political and financial realities (13). Much of that capital need is represented by the CTA, particularly its rail system. In order to mitigate forecasted declines in federal revenue and to provide for an aggressive campaign to adequately fund the CTA and its regional partner agencies, the task force's recommendation is to pursue funding for transit capital more aggressively at the local level. Value capture is thus an important capital project financing strategy for CTA to pursue.

One value capture tool used heavily by the City of Chicago is tax increment financing (TIF). TIF districts allow municipalities to set a threshold on the assessed value of the property within the district and to divert tax revenues accrued from a higher valuation into a TIF fund. The City has 153 TIF districts in place. In the past few years the rate at which TIF funds have been used to support transit-related projects has increased and a handful of station redevelopment projects have been approved with partial funding from TIF districts. State laws governing TIFs limit their application to neighborhoods and projects with certain requirements in terms of declining investment and "blight" (14). This case study differs from the preceding three by focusing on value capture and coordination efforts that are not precedential and how greater coordinated efforts could significantly expand the value capture tool box and financial reward.

\section{Project Information}

This study reviewed six specific TIF-funded transit projects that have been approved or completed in the past few. They are: 
- -Wilson Transfer Station: complete station rehabilitation and reconstruction (Red/Purple Line)

- $\quad-18^{\text {th }}$ Street Connector: track rehabilitation (Orange Line)

- $\quad$-Morgan Street Station (Green/Pink Line)

- $\quad$-Harrison Street Subway: station rehabilitation (Red Line)

- -Bryn Mawr Station: station rehabilitation, track and signal work (Red Line)

- -Illinois Medical District (IMD) Station: station rehabilitation and ADA compliance (Blue Line)

TIF funding for these projects accounts for anywhere from 2\% (Wilson Transfer Station) to 100\% (IMD and Harrison) of the total construction budget. In each case an ordinance approving an intergovernmental agreement was or is required to allow the allocation of TIF funds to CTA (15).

\section{Coordination}

The difference between Chicago and the three previous case studies is that in all of Chicago's TIF funded examples the City and CTA acted in concert but with little coordination with other parties such as local community groups and developers. New TIF districts and the original TIF ordinances and statutes are subject to Chicago City Council approval and are impacted in some way by input from community groups, developers and other stakeholders. However, the requirements for coordination when using TIF districts does not occur to the same degree as is found in the other case studies involving joint development agreements, SADs, FAR marketplaces, and other similar arrangements.

Taking that difference into consideration, the project team's conversation with a private sector group of Chicago planners and developers centered on the opportunities policymakers and transit planners in Chicago have to engage more with community and development partners (Chicago developer meeting, unpublished data). In that regard, there were two important opportunities identified where the CTA and other Chicago institutions could better coordinate to create more value capture strategies for new projects:

- Adopting a proactive approach with developers when initializing the planning process for capital construction projects.

- Taking action once large transit and/or private redevelopment projects get underway to harness all available cooperative funding mechanisms to improve transit in the area.

The first point raised by the group concerns a lack of communication they perceive when a city or a transit agency begins planning for the redevelopment of stations. WMATA's process of creating developer guideline handbooks and convening groups to ascertain possible partnerships during the planning process was especially attractive to the group.

The second opportunity stems from the observation of the group regarding recent changes to the Chicago's guidelines on parking ratios. In their opinion, had the City coordinated more closely with developers, it could have instituted a parking ratio market much like the FAR market utilized New York City.

In addition to these observations the group was also concerned that Chicago's government structure presents unique challenges to the type of coordination found in other cities. The amount of control aldermen have over City spending in their wards is potentially troublesome for the City when trying to spearhead a coordinated pursuit of value capture funding, especially for projects that might stretch across or benefit multiple wards.

\section{Project Conclusions}

The recent successful examples of using existing TIFs to completely build new transit stations are unprecedented in Chicago. Strong recommendations by the private developer community (transit-specific value capture mechanisms enacted by the state legislature, proactive contsets from taxing authorities during zoning changes similar to NYC) signal possibilities for the application of additional value capture strategies. In order to seize this opportunity, however, Chicago's taxing authorities and transit planners 
need to make every effort to expand their coordination efforts to include the local communities and developers and to lobby for a larger array of value capture instruments to be used for transit. This type of organizational change can be witnessed in WMATA's development of new approaches to their real estate program (transit agency crafted pro forma development guides for outreach to developers when taking early steps to redevelop station areas). Also Illinois statutory authorization could be amended to include transit-specific TIF and other value capture mechanisms (16).

\section{BEST PRACTICES, RECOMMENDATIONS, AND CONCLUSIONS}

\section{Best Practices}

Though none of the observed projects are perfect examples of coordination between entities during the planning, funding and execution stages New York, San Francisco and Washington, DC provide experiences that support recommendations for transit agencies, municipalities and private development partners when considering transit value capture strategies.

\section{Public Entity Coordination and Planning}

The efforts that can be made by public entities to insure the success of value capture for transit have three aspects of coordination: 1) Organizational structure; 2) Personnel makeup of various city and transit agency departments; and 3) Understanding and mutability of zoning and taxation ordinances and laws to suit transit development.

\section{Organizational Structure}

In New York, the Hudson Yards Infrastructure Corporation (HYIC) and Hudson Yards Development Corporation (HYDC) are excellent examples of public and private entities banding together to create and staff project-specific corporations that create a solid framework for coordination of all parties outside of the typical municipal and transit governance structure.

These corporations allow for direct project management and for direct communication to developer and community partners who are interested in having input and monitoring project progression. Of course, a project the size of Hudson Yards can justify such a novel approach, but what in the case of a smaller project such as Washington DC's NoMa-Gallaudet project? For the NoMa-Gallaudet project a special entity was created (Action 29). Subsequently WMATA and the District have begun to adopt a more formal, standing process to engage in the same types of activities that a separate corporation might, but without having to work through the legal and organizational issues required by project-specific corporations. These types of less formal processes can deliver the same benefits of project-specific corporations for smaller projects.

From the four case study cities an ideal organizational structure can be compiled and used as a guide for future value capture efforts. In fact, the Hudson Yards project can be seen as a near ideal case. It utilizes independent corporate structures to both communicate with stakeholder parties and manage the financial particulars of a project. These organizations may be a necessity for large project. Regardless of project size, having project or region specific corporate entities that are staffed by all stakeholders involved in transit projects using value capture - especially to support debt payments - would be an ideal arrangement.

Human Capital

Apart from organizational structures is the need to find the right staff to achieve close coordination with other government entities, private developers and community members to ensure successful value capture strategies. Every case study involved individuals with diverse and unique talents, but certain important traits stood out. Having transit staff with a diverse experience in a range of fields including real estate development, transit capital investment, and municipal government allows for lines of communication to open that might typically go unexplored.

At WMATA, the staff member responsible for managing the authority's real estate program is an excellent example of utilizing prior public and private experience to craft a proactive real 
estate plan for a public agency. This has led to WMATA's pro forma real estate development guide for rail stations identified as strong redevelopment prospects. It is an interesting and novel tool for a transit agency to employ: State goals and ensure that important stakeholders from municipal and development parties are well-informed of those goals. In order to create such documents and programs specialized staff members are necessary.

Zoning and Taxation

Once again, New York City serves as an excellent example of public entities coordinating to apply value capture mechanisms. However, in this instance New York has both a positive and negative history that underscores the importance of good coordination. As addressed in the case study the initial rezoning effort around Hudson Yards failed. According to staff members as well as those that have studied the effort, the failure was due in large part to the lack of coordination between all of the parties necessary to justify rezoning. Over a decade later, via corporate organizational prowess and better communication of intent and benefit, New York's public entities and private partners managed to engage in the type of zoning and tax reform to benefit the construction of the MTA expansion of the Number 7 line.

\section{Early Engagement of Private Partners}

As mentioned above, WMATA has implemented a process of pre-defining development requirements when engaging in station redevelopment as well as for station infill construction. Using the prior experience of staff members as well as personal and professional relationships between public entities and private developers, WMATA's team has set a standard for proactive community and developer engagement at the very earliest stages of projects.

The physical representation of this engagement is WMATA's development book, a tool to be used by WMATA staff as well as private development partners that guides the development process. The book provides political and physical self-inventory of developable land and transit station redevelopment ideas. It should be a guide to all transit agencies but has particular import for those transit agencies and municipal entities seeking to fund a redevelopment with value capture mechanisms.

\section{Efficient and Prudent Use of Public Resources}

Awareness of the risks involved when using tax-based value capture is essential and to the extent possible should be ameliorated through risk management strategies. One instructive example from these case studies is that of WMATA's NoMa-Gallaudet station where less than $25 \%$ of total station costs are being paid by a special assessment district. The size of the actual subsequent real estate developments suggest that there could have been justification for a much larger value capture contribution. WMATA's new efforts to be proactive with developers is a step in the right direction. It is an example how consistent processes conducted by knowledgeable staff in a transit system can better utilize available methods to more fully capture potential private contributions to a transit project. 


\section{Recommendations}

\section{Taxing Authorities}

Municipal and regional taxing authorities should develop close bonds with the transit system capital planning and station area redevelopment teams. Additionally reviews of all known value capture strategies should be made and assessed for their local legal applicability. Where legally authorized they should be considered for value capture application if they fit the circumstance. If sufficient legal authority is lacking, it should be sought. Furthermore special corporate structures for larger projects, with full participation by all public and private stakeholders, should be considered to ameliorate risk and clearly communicate project progress, benefits and the ongoing fiscal health of the project and its parent financing authorities. Strategies of seeking out new sources of funding via innovative mechanisms and partnership with local stakeholders can serve to insulate municipal and regional taxing authorities against known uncertainties of federal and state capital funding programs.

\section{Transit Agencies and Capital Planners}

Transit agencies must cultivate specialized staff experience which includes the ability to properly interface with both their constituent taxing authorities and the developers that may have interest in contributing to projects. Developing this institutional capacity is no easy task, but even one or a few staff members with prior relevant work experience and a desire to use creative means to fund network improvements can be enough to maintain developer interest and assemble mutually interested parties from other public entities. This is especially vital for any system with multiple redevelopment opportunities. A proactive staff member with specialized knowledge can lead a team in creating pro forma developer requirement documents and will prepare transit agencies for seeking private financial input for future transit projects.

\section{Private Developers}

Developers must be open to giving feedback to the transit systems and seeking an understanding of benefits of transit to their developments. For example, as has been documented in the literature there are rent premiums associated with proximity to transit facilities. While it is incumbent upon transit and other public authorities to properly communicate their capital needs, developers must be willing to engage in the process of visioning and funding future transit improvements that are mutually beneficial to them and to the public interest. Similarly when public entities are planning to build new facilities there must be a willingness for a partnership with private entities to construct projects that are of mutual interest.

\section{Conclusions}

The real estate adage about unique locations, that each development has its own specific strengths and weaknesses that impact market decisions by all parties, applies equally to utilizing value capture as a funding mechanism for transit improvements. Each jurisdiction has unique local constituencies, specific geography, funding variances, fluctuating governmental constraints, distinctive opportunities and the challenges of dealing with future uncertainties. Value capture offers a variety of funding methods and can be creatively utilized to structure a local transit funding program which meets local requirements.

New York City, San Francisco and Washington, DC provide best practices of how effective coordination can serve other cities, transit agencies and real estate developers in maximizing the of use value capture to realize successful transit projects. In Chicago, the transit system benefits from a municipal government that gives high priority to transit investments. So much so that the City is willing to use tax increment financing - the existing value capture mechanisms it controls for such improvements -- even though the mechanisms were not originally established for that purpose. Applying more sophisticated value capture strategies as done in the other cities studied could be an opportunity for Chicago in the future. 


\section{REFERENCES}

1) San Francisco Municipal Transportation Agency. (2013). Muni's history. http://www.sfmta.com/aboutsfmta/our-history-and-fleet/muni-history. Accessed May 19, 2013.

2) San Francisco Planning Department. (2010). Parkmerced development agreement. City of San Francisco.

3) San Francisco Planning Department. (2011). Parkmerced transportation plan. San Francisco, CA: City of San Francisco.

4) San Francisco County Transportation Authority. (2014). 19 $9^{\text {th }}$ Avenue Transit Study. San Francisco, CA. 5) Washington Metropolitan Area Transit Authority. (2012). Metro facts. Washington, DC: Washington Metropolitan Area Transit Authority.

6) Washington Metropolitan Area Transit Authority. (2008). WMATA subsidy allocation methodology. Washington, DC: Washington Metropolitan Area Transit Authority.

7) Metropolitan Washington Council of Governments. (2007). WMATA vision and need for dedicated funding. Washington, DC: Metropolitan Washington Council of Governments.

8) pbConsult. (2011). New york avenue-florida avenue- gallaudet university metro station: A case study. Washington, D.C.: AASHTO.

9) Washington Metropolitan Area Transit Authority. (2013). Joint Development at Metro: Strategies, Lessons Learned, and Value Capture. Unpublished manuscript.

10) Hudson Yards Development Corporation. (2013). The Hudson Yards Project. Unpublished manuscript.

11) Hudson Yards Infrastructure Corporation. (2013). 2013 annual report. http://www.nyc.gov/html/hyic/html/annual_report/annual_report.shtml. Accessed May 14, 2013.

12) van der Veen, M. (2009). Case Study Hudson Yards, New York No. 7 Subway

Extension. Contracting For Better Places: A Relational Analysis Of Development Agreements In Urban Development Projects. (pp. 147-190) IOS Press.

13) NEIL Public Transit Task Force. (2014). Transit for the 21st century Illinois Department of Transportation.

14) Metropolitan Planning Council. (2012). Funding transit with TIFs.

http://www.metroplanning.org/news/newsletters/155. Accessed April 10, 2014.

15) Chicago Transit Authority. (2014). Finance \& Budget.

http://www.transitchicago.com/business/financebudget.aspx. Accessed April 14, 2014.

16) Illinois Compiled Statutes. 65 ILCS 5/ Illinois Municipal Code. Undated.

http://ilga.gov/legislation/ilcs/ilcs4.asp?DocName=006500050HArt\%2E+11+Div\%2E+74\%2E4\&ActID= 802\&ChapterID=14\&SeqStart=208800000\&SeqEnd=210900000. Accessed March 4, 2014. 